\title{
TINDAK PIDANA PEMERKOSAAN DALAM PERSPEKTIF PERLINDUNGAN HUKUM PEREMPUAN
}

\author{
Teo Dentha Maha Pratama, Anak Agung Sagung Laksmi Dewi, Ni Made Sukaryati Karma \\ Fakultas Hukum Universitas Warmadewa, Denpasar-Bali, Indonesia \\ teodentha552@gmail.com, laksmiidewi@gmail.com, sukariati64@gmail.com
}

\begin{abstract}
Abstrak
Tindak pidana merupakan perbuatan yang dilarang oleh aturan hukum yang disertai ancaman berupa sanksi seperti penerapan pidana tertentu. Tindak Pidana Pemerkosaan dalam KUHP termasuk dalam kategori kesusilaan. Kejahatan terhadap perkosaan bisa dilihat dalam Buku II KUHP. Berkaitan dengan hal tersebut, kajian ini menyoroti dua isu: (1) perlindungan hukum terhadap perempuan korban pemerkosaan menurut perspektif hukum perempuan dan (2) sanksi pidana terhadap pelaku tindak pidana pemerkosaan terhadap perempuan. Penelitian ini menggunakan metode normatif dikarenakan terdapatnya norma yang kosong. Perlindungan hukum terhadap perempuan sebagai korban pemerkosaan dapat dikorelasikan dalam Pasal 285 KUHP Ayat (1) dan Ayat (2) serta Undang-Undang Kekerasan dalam Rumah Tangga (KDRT) Nomor 23 Tahun 2004 Pasal 46 tentang Kekerasan Seksual dalam rumah tangga. Aturan tersebut hanya mengatur tentang sanksi bagi pelaku tindakan pemerkosaan terhadap perempuan. Sanksi bagi pelaku pemerkosaan terhadap perempuan diatur dalam Pasal 285 Ayat (1) dan Ayat (2) yang juga dapat dilihat dalam Undang-Undang Nomor 23 Tahun 2004 Pasal 46 tentang Penghapusan Kekerasan dalam Rumah Tangga dengan pidana penjara atau denda yang sama.
\end{abstract}

Kata Kunci: Tindak Pidana Pemerkosaan; Perempuan; Perlindungan Hukum

\begin{abstract}
A criminal act refers to an act that is prohibited by legal regulations accompanied by threats in the form of sanctions such as the application of certain crimes. The criminal act of rape in the Criminal Code is included in the category of decency. Criminal acts of rape can be referenced from the Book II of the Criminal Code. In this regard, this study focuses on two issues: (1) legal protection of women victims of rape from a women's legal perspective and (2) criminal sanctions against perpetrators of the criminal acts of rape against women. This study makes use of the normative method because there is an empty norm. Legal protection for women as victims of rape correlatable in Article 285 of the Criminal Code Paragraph (1) and Paragraph (2) as well as the Domestic Violence Law (KDRT) Number 23 of 2004 Article 46 concerning Sexual Violence in the household. This regulation only regulates the sanctions for perpetrators of the acts of rape against women. Sanctions for perpetrators of the rape against women are regulated in Article 285 Paragraph (1) and Paragraph (2) which can also be seen in Law Number 23 of 2004 Article 46 concerning the Elimination of Domestic Violence with imprisonment or the same fine.
\end{abstract}

Keywords: Criminal Act of Rape; Women; Legal Protection

\section{PENDAHULUAN}

Salah satu bentuk dari kajian hukum yang sangat penting dan berhubungan dengan kehidupan kita adalah kajian hukum pidana. Hukum pidana dapat kita lihat bahwa rumusan didalamnya mengandung perintah serta larangan atau juga suatu keharusan dimana jika tidak dipatuhi atau dilanggar maka pelanggarnya dapat diancam pidana berupa sanksi (akibat hukum). Hukum pidana terbagi atas dua bagian yang pertama adalah hukum pidana materiil yang isinya mengenai petunjuk-petunjuk serta berbagai uraian tentang bagaimana tindak pidana tersebut dan hukum pidana formil yaitu mengenai cara dari suatu Negara dengan perantaranya yaitu para pejabatnya untuk menggunakan haknya dalam 
menjatuhkan pidana. Perbuatan inilah yang mana dianggapdan tebukti melangar aturan-aturan merupakan suatu tindak pidana.

Salah satu tindak pidana yang sering terjadi di masyarakat yaitu tindak pidana pemerkosan yang dengan mana korban dari tindak pidana pemerkosaan ini cenderung dan mayoritas dialami oleh perempuan. Tindak pidana terhadap pemerkosaan dapat ditemukan pengaturannya dalam Kitab Undang-Undang Hukum Pidana yaitu pada pasal 285 Kitab Undang-Undang Hukum Pidana (KUHP), yang mana unsurnya seperti barang siapa, melakukan pemaksaan, dengan ancaman atau kekerasan, melakukan persetubuhan di lua perkawinan (Lamintang, 1997).

Perlindungan hukum terhadap perempuan sebagai korban pemerkosaan saat ini belum dapat kita temui secara spesifik dan jelas pengaturannya dalam Undang- Undang Perlindungan Perempuan dan Anak seperti kejelasan mengenai pasal hingga sanksi hukumnya, untuk itu perlindungan hukum terhadap perempuan korban pemerkosaan haruslah segera di tindak lanjuti sehingga menghindari adanya kekosongan norma terkait perlindungan hukum bagi para korban yaitu disini adalah perempuan.

Salah satu dampak dari adanya perkembangan kehidupan atau era globalisasi ini yang tentunya sangat pesat, berbagai tindak kejahatan pun semakin meningkat baik dari segi kualitas maupun kuantitasnya. Dilihat dari pelaku dan para korban yang begitu banyak kasusnya hingga saat ini, kita ketahui bahwa dinamika kejahatan tersebut massif dan sulit untuk berhenti. Salah satu bentuk kejahatan yang sangat merugikan dan meresahkan masyarakat adalah kejahatan asusila khususnya pemerkosaan. Pemerkosaan merupakan salah satu dari sekian banyak pelanggaran terhadap Hak Asasi Manusia khususnya untuk kaum perempuan.

Penelitian ini mengkaji tentang perlindungan hukum terhadap perempuan korban pemerkosaan menurut perspektif hukum perempuan dan sanksi pidana terhadap pelaku tindak pidana pemerkosaan terhadap perempuan.

\section{METODE PENELITIAN}

Metode penelitian yang digunakan dalam penyusunan materi penelitian ini adalah normatif, dengan merujuk pada pendekatan perundang-undangan sert konseptual. Ada beberapa sumber bahan hukum baik primer atau sekunder yang digunakan seperti KUHP dan Undang-Undang No. 23 tahun 2004 tentang penghapusan KDRT, hingga Undang-Undang Nomor 23 Tahun 2002 tentang Perubahan atas Undang-Undang Nomor 35 Tahun 2014 tentang Perlindungan Perempuan dan Anak. Selain itu juga terdapat bahan hukum lainnya dari buku-buku ilmiah, jurnal, literatur dan lain sebagainya. Data dikumpulkan melalui studi kepustakaan, yang meliputi mencari undang-undang yang digunakan dan kajian-kajian pustaka yang berkaitan dengan objek penelitian. Data dianalisis dengan metode interpretasi dan penalaran yang meliputi menginterpretasikan dan menjelaskan undang-undang yang mengatur tentang pemerkosaan perempuan. Kemudian, analisis data disajikan secara deskriptif menggunakan kata-kata.

\section{HASIL DAN PEMBAHASAN Perlindungan Hukum terhadap Perempuan Korban Pemerkosaan menurut Perspektif Hukum Perempuan}

Perbuatan pemerkosaan adalah salah satu bentuk kejahatan terhadap seksual yang umumnya terjadi pada perempuan dan anak, namun tidak memungkiri juga terjadi pada kaum laki-laki, mengingat perkembangan saat ini. Pemerkosaan merupakan suatu bentuk perbuatan kriminal yang termasuk isu seksual yang terjadi ketika seseorang memaksakan kehendak birahinya kepada manusia lain untuk mau mengikuti hasratnya melakukan hubungan seksual dalam bentuk penetrasi vagina dengan penis, yang dilkukan secara paksa dan/atau dengan cara kekerasan. Dalam kamus besar bahasa Indonesia, perkosaan memiliki arti atau makna yaitu suatu perbuatan menggagahi atau melanggar dengan kekerasan. Sedangkan pemerkosaan sendiri diartikan sebagai suatu cara, proses, perbuatan yang melanggar kesusilaan terhadap orang lain, yang dilakukan dengan cara paksa dan/atau dengan kekerasan pula (Purwadarminta, 1999).

Penulis sendiri cenderung mengartikan persetubuhan sesuai apa yang dikemukakan oleh A. Zainal Abidin Farid dengan alasan bahwa Indonesia merupakan suatu Negara yang berbudi luhur menjunjung tinggi nilai-nilai moral yang berkembang di masyarakat sehingga mengenai tindakantindakan seperti pemerkosaan merupakan bentuk tindakan yang menjadi kecaman bagi seluruh 
masyarakat karena dianggap merampas harkat, martabat manusia dengan label sikap immoral. Demikian juga perbuatan bersetubuh ini dipandang telah terjadi, apabila seseorang telah memasukkan kelaminnya ke dalam milik orang lain, adanya ejakulasi disini tidak begitu disyaratkan (Farid, 1993).

Menurut Arif Gosita sendiri perlindungan hukum merupakan hubungan sebagai hasil interaksi terhadap fenomena yang ada dan terjadi sehingga saling memengaruhi satu sama lain (Gosita, 1989). Sedangkan Shanty Dellyana juga mengemukakan pendapat mengenai perlindungan terhadap perempuan merupakan suatu hak dan kebebasan terhadap perempuan untuk dapat melaksanakan kewajiban dan mendapatkan haknya sebagaimana diberikan padanya tanpa adanya paksaan dari pihak lain (Dellyana, 1988).

Perlindungan Hukum Terhadap Perempuan dapat ditemui dalam Undang- Undang Nomor 7 Tahun 1984 tentang pengesahan konvensi penghapusan segala bentuk diskriminasi terhadap wanita. Selain itu, diantara berbagai perjanjian perjanjian internasional tentang HAM, terdapat pula konvensi penghapusan segala bentuk diskriminasi terhadap perempuan yang juga merupakan bentuk nyata konvensi perlindungan terhadap perempuan. Pasal 1 ayat (3) dan Pasal 3 ayat (3) menjelaskan mengenai pelarangan hukum bagi siapapun yang melakukan diskriminasi yang didasarkan pada jenis kelamin seseorang.

Aturan lainnya pun dikehendaki harus meniadakan perilaku diskriminasi dalam setiap aspek kehidupan, sosial, politik, budaya, ekonomi maupun hukum. Dalam Undang-Undang Nomor 39 tahun 1999 tentang HAM juga mendukung dengan selalu ditunjukannya suatu aturan bagi semua orang tanpa memandang jenis kelamin dan golongan, dalam memberikan perlindungan juga terhadap perempuan, anak dan masyarakat adat sehingga aturan hukum disini tidak menyasar hanya padakaum yang lemah, namun seua sama dimata hukum sebagimana bunyi asas hukum itu sendiri.

Setalah ditetapkannya UU KDRT maka ketentuan mengenai ranah keluarga dipandang luas hingga dapat disebut juga menjadi ranah masyarakat sehingga perlindungan hukumnya dirasa menjadi lebih jelas dan memadai. Perempuan sering kali dianggap sebagai kaum yang lelah dan dinomor duakan oleh tradisi dan budaya di masyarakat sehingga untuk menikmati hak- haknya diperlukan perjuangan dan pengakuan ekstra dan selalu berdampak pada posisi yang tidak beruntung. Bentuk perlindungan dalam menikmati hak-haknya sebagimana diberikan melalui Undang-Undang Nomor 11 Tahun 2005 tentang pengesahan Konvenan Internasional tentang hak ekonomi, sosial dan budaya.

Peraturan Presiden Nomor 5 Tahun 2010 tentang RPJMN Tahun 2010-1014 juga memberikan pernyataan bahwa masih rendahnya kualitas hidup serta peran perempuan dalam kehidupan masyarakat dan ini disebabkan: adanya kesenjangan gender atau jenis kelamin sehingga dalam pengaksesan pembangunan serta penguasaan sumber daya masih kurang, selainitu juga karena rendahnya keterlibatan atau partisipasi perempuan dalam hal politik, seperti untuk mengisi jabatan publik dan ekonomi, di bidang bencana alam hingga konflik sosial.

Pemerintah dalam memberikan perlindungan terhadap perempuan tertuang pula pada Intruksi Presiden Nomor 9 Tahun 2000 tentang pengapusan jenis kelamin yang mengharuskan setiap institusi penyelenggara pemerintah mengintegrasikan pengarusutamaan jenis kelamin dalam program dan budgetnya. Perempuan yang cenderung sering menjadi sasaran para predator seks diharapkan dapat lebih mawas diri dan waspada dalam berpakaian dan bersikap, jangan sampai mengundang para predator atau pelaku seks untuk merealisasikan niat jahatnya. Selain itu peran serta masyarakat juga sangat penting, dimana harus sadar akan kehadiran ancaman-ancaman dari para pelaku pemerkosaan sehingga lebih mengawasi putra-putri mereka, keluarga mereka dan orag disekitar mereka. Jangan sekal-seklai mengucilkan para korban, gunakanlah pendekatan psikologis untuk membantu korban bukannya mengucilkan mereka.

Dalam hal jenis dari pemerkosaan, pemerkosaan dapat berupa sadistis pemerkosaan, korban (victim), eksploitasi pemerkosaan, dononution, Angea serta sudective, sebagaimana menurut Kusumah (1981). Dari beberapa peraturan dan perundang-undangan yang tersurat maupun tersirat memberikan perlindungan terhadap perempuan dalam satu sisi menjadi angin segar bagi perempuan tetapi disisi lain masih perlu dikaji lebih jauh dalam implementasi, penerapan dan penjabaran lebih lanjut.

\section{Sanksi Pidana terhadap Pelaku Tindak Pidana Pemerkosaan terhadap Perempuan}

Perkosaan atau dalam bahasa inggris (rape) merupakan suatu bentuk kekerasan terhadap seksualisme, sedangkan kekerasan tersebut dapat dikategorikan menjadi kekerasan baik secara fisik, mental, 
emosional dan hal-hal yang sangat menakutkan yang dapat dialami para korban. Perkosaan adalah suatu penetrasi atau persetubuhan berupa pemaksaan untuk memasukan kelamin miliknya ke dalam milik orang lain yaitu disini perempuan yang mana perbuatan tersebut tidak dikehendaki atau tanpa persetujuan karena merupakan tindakan yang diikuti dengan pemaksaan baik secara fisik maupun mental.

Perbuatan pemerkosaan itu merupakan perbuatan yang tidak baik karena:

a. Bertentangan dengan nilai-nilai di masyarakat seperti moral dan agama

b. Membuat perempuan tersiksa dan merasakan sakit

c. Melanggar hak asasi manusia milik orang lain

Setiap perbuatan yang melanggara aturan hukum pasti akan dikenai sanksi, entah dalam bentuk administratif, denda maupun pidana. Dalam kasus pemerkosaan sendiri yang termasuk delik pidana, dalam pengaturannya kita akan jumpai sanksi pidana. Sanksi Pidana sendiri adalah suatu hukuman yang merupakan hubungan sebab akibat, dimana sebabnya adalah kasus atau perbuatan yang dilakukan yang mana melanggar norma atau aturan dan akibat adalah hukumnya, orang yang terkena akibat inilah akan dijatuhi sanksi sesuai dengan perbuatan yang dilakukan seperti sanksi berupa masuk penjara, denda ataupun terkena hukuman lainnya dari pihak berwajib yang menentukan.

Sanksi pidana pada dasarnya merupakan suatu penjaminan untuk melakukan rehabilitasi atau pemulihan perilaku terhadap pelaku kejahatan tersebut, namun tidak jarang bahwa sesungguhnya sanksi pidana itu meupakan ancaman yang diciptakan untuk menangani kebiasan manusia yang suka melanggar (Andrisman, 2009). Tujuan pemidanaan sesungguhnya dilakukan guna upaya untuk mencedah dilakukannya kejahatan di kemudian hari atau masa yang akan datang, tujuan diadakannya pemidanaan diperlukan untuk mengetahui sifat dasar hukum dari pidana. Bahwa dalam konteks dikatakan Hugo De Groot "malim pasisionis propter malum actionis" yaitu penderitaan jahat sebagai hasil dari perbuatan jahat.

Berdasarkan pendapat tersebut, tampak adanya pertentangan mengenai tujuan pemidanaan, yakni teori absolut yang berpandangan bahwa pembalsan dilakukm melalui pemidaan itu sendiri dan mereka yang menyatakan sebaliknya bahwa terdapat tujuan atau maksud baik dan positif dibalik pemidanaan atau teori tujuan, serta pandangan yang menggabungkan dua tujuan pemidanaan tersebut (Muladi, 2008).

Tindak pidana pemerkosaan dapat dilihat penaturannya dalam Kitab Undang- Undang Hukum Pidana lebih spesifiknya pada pasal 285 Kitab Undang-Undang Hukum Pidana (KUHP) yang berbunyi bahwa siapa saja yang memaksa seorang wanita atau perempuan untuk bersetubuh dengannyatanpa adanya ikatan perkawinan, dengan cara kekerasan dapat dihukum pidana selama dua belas tahun penjara. Selanjutnya, Kekerasan seksual juga diatur dalam Undang-Undang Nomor 23 Tahun 2004 Pasal 46 tentang Penghapusan Kekerasan Dalam Rumah Tangga mengatur mengenai kekerasan seksual yaitu setiap orang dapat dipidana penjara selama 12 tahun ata denda sebanyak R.36.000.000,00 (tiga enam juta rupiah) jika tebukti melakukan perbuatan seperti yang dimaksud dalam pasal 8 huruf a Undang-Undang ini. Merujuk pada RKUHP yang sedang bermasalah saat ini, khususnya pada Pasal 480 ayat (1) dan ayat (2), per 28 Agustus 2019 yang segera akan disahkan DPR RI, pelaku pemerkosaan terhadap pasangannya yang sah dapat dijatuhi hukuman pidana paling lama selama 12 tahun penjara.

Fenomena kejahatan pemerkosaan sering dan banyak terjadi di masyarakat, untuk itu kita harus waspada dan lebih berhati-hati dalam melakukan suatu aktifitas di dalam maupun di luar lapangan. Contoh kasus pemerkosaan terhadap perempuan yang terjadi di Bali yang terjadi di Sanur dekat penginapan, dimana korban dan pelaku kenal satu sama lain melalui aplikasi chatting, korban yang merasa tak terima dengan perbuatan pelaku akhirnya melapor ke pihak berwajib, setelah itu dilakukan pemeriksaan lebih lanjut. Dari sini kita ketahui bahwa social media juga berpengaruh dalam perkembangan kejahatan seksual yang terjadi untuk itu bijakla bersosial media. Karena para pelaku dapat melakukan segala cara untuk merealisasikan niatnya, sehingga kita harus pintar dalam membawa diri dan berinteraksi dengan orang- orang disekitar kita baik secara langsung maupun tidak langsung melalui aplikasi pesan.

Merujuk pada Kitab Undang-Undang Hukum Pidana (KUHP) dan Undang-Undang Penghapusan Kekerasan Dalam Rumah Tangga mengenai kekerasan seksual yang dialami oleh setiap perempuan 
terutama mengenai pengenaan sanksi yang diberlakukan untuk para pelaku kejahatan diharapkan para pelaku mendapatkan efek jera atas perbuatan dan kasus yang mereka telah lakukan. Bagi para Lembaga terutama Pusat Pelayanan Terpadu Pemberdayaan Perempuan dan Anak (P2TP2A) diharapkan lebih sigap memberikan pengayoman, pelayanan serta bimbingan kepada masyarakat mengenai kasus- kasus yang terjadi di sekitar kita terutama kasus pemerkosaan. Biasanya para korban akan mengalami trauma yang cukup hebat setelah mengalami peristiwa tersebut, untuk itu pendekatan oleh para ahli yang khusus dibidangnya seperti psikiater atau psikolog sangat penting, begitu juga peran orang terdekatnya seperti keluarga atau orang tua misalnya.

\section{SIMPULAN DAN SARAN \\ Simpulan}

Ada beberapa hal yang menjadi simpulan penelitian ini, yakni:

1. Perlindungan hukum terhadap perempuan korban pemerkosaan belum ada yang mengatur mengenai pasal tersebut dimana dalam pasal 285 KUHP ayat (1) dan ayat (2) dan UndangUndang KDRT Nomor 23 Tahun 2004 Pasal 46 tentang kekerasan seksual dalam rumah tangga hanya mengatur tentang sanksi bagi pelaku yang melakukan pemerkosaan terhadap perempuan dan Pusat Pelayanan Terpadu Pemberdayaan Perempuan dan Anak ( P2TP2A ) selaku lembaga hanya bisa memberikan perlindungan terhadap masyarakat terutama perempuan dan anak mengenai kasus-kasus yang berhubungan dengan tugas dari ( P2TP2A ).

2. Sanksi bagi pelaku pemerkosaan terhadap perempuan diatur dalam Pasal 285 ayat (1) dan ayat (2) pelaku pemerkosaan atau ancaman kekerasan memaksa wanita bersetubuh dengan dia di luar perkawinan, diancam pidana penjara paling lama dua belas tahun penjara dan Kekerasan seksual juga diatur dalam Undang-Undang Nomor 23 Tahun 2004 Pasal 46 tentang Penghapusan Kekerasan Dalam Rumah Tangga pidana penjara paling lama 12 ( dua belas ) tahun atau denda paling banyak Rp. 36.000.000,00 ( tiga puluh enam juta rupiah).

\section{Saran}

Bertolak dari apa yang ditemukan penelitian ini, ada beberapa saran yang dapat diberikan, yakni:

1. Bagi Pemerintah dalam hal ini sebagai pejabat yang memiliki kewenangan, perlu setidaknya melakukan pengkajian berkala terjhadap aturan terkait seperti Undang-Undang Perlindungan Perempuan terkait sanksi bagi pelaku pemerkosaan terhadap perempuan, agar dapat menampung segala hal terkait kejahatan seksual khususnya perkosaan dan nantinya hal tersebut tidak terulang kembali serta mampu memberikan efek jera bagi pelaku pemerkosaan.

2. Bagi para penegak hukum seperti kepolisian, kejaksaan dan kehakiman agar lebih sigap dalam menangani setiap kasus terkait pemerkosaan khususnya serta mampu memberikan putusan yang setimpal sesuai dengan ketentuan Undang-Undang bagi para pelaku pemerkosaaan terhadap perempuan agar tidak ada lagi perempuan yang menjadi korban kejahatan seksual terutama pemerkosaan.

3. Bagi masyarakat khususnya kaum perempuan yang cenderung sering menjadi sasaran para predator seks diharapkan dapat lebih mawas diri dan waspada dalam berpakaian dan bersikap, jangan sampai mengundang para predator atau pelaku seks untuk merealisasikan niat jahatnya. Selain itu masyarakat juga harus sadar akan kehadiran ancaman-ancaman dari para pelaku pemerkosaan sehingga lebih mengawasi putra-putri mereka, keluarga mereka dan orag disekitar mereka. Jangan sekali-sekali mengucilkan para korban, gunakanlah pendekatan psikologis untuk membantu korban bukannya mengucilkan mereka.

\section{DAFTAR PUSTAKA}

Andrisman, T. (2009). Hukum Pidana: Asas-asas dan Dasar Aturan Hukum Pidana di Indonesia. Penerbit Universitas Lampung.

Dellyana, S. (1988). Wanita dan Anak di Mata Hukum. Liberty.

Farid, A. Z. A. (1993). Hukum Pidana. Sinar Grafika.

Gosita, A. (1989). Masalah Perlindungan Anak. Akademika Presindo.

Kusumah, M. W. (1981). Aneka Permasalahan Dalam Ruang Lingkup Kriminologi. Alumni.

Lamintang, P. A. F. (1997). Dasar-dasar Hukum Pidana Indonesia. Citra Aditya Bakti.

Muladi. (2008). Kasus Soeharto Sudah Selesai. Perpustakaan Nasional RI. 
Purwadarminta, W. J. S. (1999). Kamus Umum Bahasa Indonesia. Balai Pustaka.

Kitab Undang-Undang Hukum Pidana

Undang-Undang Nomor 23 Tahun 2002 tentang Perubahan atas Undang-Undang Nomor 35 Tahun 2014 tentang Perlindungan Perempuan dan Anak

Undang-Undang Nomor 23 Tahun 2004 Pasal 46 tentang Penghapusan Kekerasan Dalam Rumah Tangga

Undang-Undang Nomor 39 Tahun 1999 tentang Hak Asasi Manusia 